\title{
DESAPROPRIAÇÃO E SUAS INTERFACES: A DOMINÂNCIA DOS CABEDAIS TEÓRICOS PARA A APLICABILIDADE PRÁTICA
}

\author{
Samantha Stanco de Jesus ${ }^{1}$ \\ Daniel Sachs Silva ${ }^{2}$
}

RESUMO: Objetiva-se demonstrar as formas necessárias e pontuais de intervenção Estatal possíveis na propriedade privada. Para poder legislar sobre o instituto da desapropriação é indispensável que se tenha proficiência e competência, no sentido de habilitação e alçada jurisdicional. À medida que o crescimento populacional avança, mais necessário se faz a abrangência do entendimento de "bens comuns" e, é nesse sentido, quando tratamos da utilidade pública, da conversão do inepto em benefício da comunidade que a desapropriação se embasa e perpetua.

Palavras-chave: Desapropriação. Expropriação. Função-Social. Utilidade-Pública.

\section{INTRODUÇÃO}

O presente trabalho tem como objetivo demonstrar quando ocorre uma desapropriação e a sequência da intervenção no imóvel realizada pelo Estado, extinguindo o vínculo entre o proprietário e o bem.

Abordará, também, do ponto de vista histórico, a desapropriação para vários fins, como: desapropriação por necessidade pública ou utilidade pública, para fins de reforma agrária, entre outras.

Outrossim, poderão mostrar quais são os objetos e sujeitos dessa relação jurídica, contribuindo para uma adequada distribuição da propriedade, ou seja, é possível que

\footnotetext{
${ }^{1}$ Advogada, mestranda em Direito da Saúde- Dimensões Individuais e Coletivas, pela universidade Santa Cecília (UNISANTA)Pós- graduada em Direito de Família e Sucessões, pela Damásio Educacional. Pósgraduada em Ciências Forenses - Perícia Criminal, pelo Instituto Paulista de Estudos Bioéticos e Jurídicos (IPEBJ)Graduanda em Ciências Biológicas, pela Universidade Anhembi Morumbi. Email:stancoadvocacia@yahoo.com.

${ }^{2}$ Advogado, mestrando em Direito da Saúde- Dimensões Individuais e Coletivas, pela universidade Santa Cecília (UNISANTA). Pós- graduado em Direito Processual Civil, pela Universidade Católica de Santos (UNISANTOS). Pós- graduado em Direito da Seguridade Social, pela Faculdade Legale. Email:advdanielor@gmail.com.
} 
determinada área, devido a desapropriação de um bem, melhore as condições de certa região, que antes eram adversas.

$\mathrm{Na}$ Constituição Federal muitas vezes o direito de propriedade, que é um direito Constitucional, é superado pelo direito da sociedade, ou seja, é possível que o proprietário perca o seu bem, para que possa ser atendido um bem maior - que seria o bem de toda a sociedade. Sempre houve muita discussão acerca do direito de propriedade e sua proteção, pois, como este é um direito constitucional de caráter absoluto, trata-se de um direito inviolável. Então vem a Administração Pública em alguns casos e intervêm na propriedade de alguém, por um bem maior coletivo.

Com o advento da atual Constituição, a concepção do direito de propriedade se modifica substancialmente, com novas regras no ordenamento jurídico.

Em razão desse fato, vem crescendo o número de conflitos - não apenas pelas novas normativas jurídicas, mas pela discussão que se dá nas relações entre a Administração Pública e o proprietário do bem, configurando o conflito entre o público e o privado.

\section{Conceito de desapropriação e seu cumprimento da função social}

Apesar da palavra desapropriação ter diversas concepções, traremos a baila o conceito de dois dos maiores doutrinadores.

Desapropriação é a retirada da propriedade com indenização integral, a que a Constituição de 1967 , art. I5o, \& $2^{\circ}$, $\mathrm{I}^{\mathrm{a}}$ parte, exige ser prévia e justa”(MIRANDA, I968, p. 331).

Desapropriação ou expropriação é a transferência compulsória da propriedade particular para o poder público ou seus delegados, por necessidade ou utilidade pública, ou por interesse social, mediante prévia e justa indenização, e, ainda, por desatendimento às normas do Plano Diretor (desapropriação - sanção, art.ı82, § $4^{\circ}$, III, da CF), neste caso com pagamento em títulos da dívida pública municipal, aprovados pelo Senado Federal” (MEIRELLES, 1994, p. 303). 
É muito utilizado, quando se fala em desapropriação, a expressão expropriação, que embora alguns fazem distinção entre elas (desapropriação e expropriação), a maioria dos doutrinadores utiliza indiferentemente os dois termos, para se referir a mesma coisa.

A Carta Magna protege a propriedade, assegurando, portanto, o direito ao bem imóvel. Contudo, para assegurar o pleno direito do uso da propriedade é necessário o cumprimento de exigências (a desapropriação deve cumprir a função social).

Esta desapropriação é feita não por culpa do proprietário, mas sim porque é preciso o uso daquela propriedade por um bem maior, ou seja, a desapropriação ocorre, por exemplo, para que sejam construídas vias públicas para a circulação de veículos.

Neste sentido o parecer do Ministro Maurício Corrêa:

$$
\begin{aligned}
& \text { Encontra ressonância na doutrina e na jurisprudência a competência dos demais } \\
& \text { entes da Federação para proceder à desapropriação, por interesse social, de imóvel } \\
& \text { rural, com pagamento de prévia e justa indenização em dinheiro. Aqui não se } \\
& \text { cogita se a propriedade é produtiva, se é latifúndio ou não. Não se trata de sanção } \\
& \text { pelo mau uso da propriedade. Na realidade, o ente estatal, para desenvolver } \\
& \text { políticas públicas relacionadas com interesse social específico, expropria e paga a } \\
& \text { devida indenização ao expropriado, como no caso, sem que com isso invada } \\
& \text { competência própria da União Federal. (SS 2.217, Rel. Min. Maurício Corrêa, DJ } \\
& \text { o9/o9/03). }
\end{aligned}
$$

Então essa desapropriação é válida quando há necessidade para o poder público, no entanto, essa desapropriação exige a justa e prévia indenização em dinheiro.

Quando tratamos sobre a forma de aquisição da propriedade na desapropriação, nos ensina Mazza (2013);

A característica mais importante da desapropriação reside no fato de ser uma forma originária de aquisição da propriedade, na medida em que aquisição não está vinculada a situação jurídica anterior. Assim, o bem expropriado ingressa no domínio público livre de ônus e gravames que eventualmente o atinjam.” (MAZZA 2013 p 620) 


\section{Desapropriação que não cumpre a função social}

Neste modo de desapropriação a indenização paga ao proprietário do bem não é feita em dinheiro, mas sim, em títulos da dívida pública.

Com a terra improdutiva, esta torna-se desvalorizada e o poder Público a utiliza para outros fins que sejam mais úteis à sociedade como um todo, ou seja, o poder Público acaba por transformar essa terra em uma terra produtiva.

A desapropriação nasce quando surge o interesse público: interesse social para desenvolvimento da política urbana, interesse social para fins de reforma agrária e o interesse

social para erradicação de propriedade nociva. A desapropriação poderá muitas das vezes ser confundida com outras espécies de indenização a proprietários de imóveis. Para podermos fixar bem essas diferenças, iremos citar uma a uma:

A) Requisição - Esta recairá sobre bens móveis, imóveis, porém somente no caso do artigo 5으 XXV da C.F., onde diz que o proprietário só será indenizado no caso de iminente perigo público.

B) Ocupação temporária de terrenos vizinhos - Ocorre quando o imóvel particular é utilizado pelo poder público para um determinado fim, como por exemplo, alguma propriedade que é usada para zona eleitoral no dia de votação e se esta ocupação temporária for de natureza coativa pode se confundir com a requisição. A indenização da ocupação temporária ocorre no final do uso do imóvel.

C) Servidão administrativa - Esta não retira a propriedade do particular, apenas restringe seu uso no atendimento a interesse público. É um ônus real que a administração impõe ao proprietário do imóvel para a realização de obras ou serviços públicos ${ }^{3}$. Em algumas hipóteses desta servidão, quando não houver prejuízo ao proprietário, pela utilização do imóvel, esta então nem será 
indenizada, e mesmo que se demonstre sua indenização, a mesma será bem menor que o valor de uma desapropriação.

\section{Bens suscetíveis de desapropriação}

Quando pensamos em desapropriação, vem à nossa mente, principalmente, os imóveis. Mas estes não são os únicos bens que podem ser desapropriados. Assim sendo, nem todos os bens podem sofrer algum tipo de sanção.

Os bens que podem ser desapropriados estão mencionados no artigo $2^{\circ}$ do decreto 3.365/4I, em que estão relacionados os bens móveis, imóveis, os direitos autorais, os privilégios de invenção, os semoventes, as ações de sociedades anônimas, os arquivos e documentos de

valor artístico ou histórico, ou seja, tudo aquilo que for necessário para atingir uma finalidade de interesse público. A desapropriação do espaço aéreo e do subsolo só se impõe quando resultar prejuízo patrimonial ao solo do proprietário. Por exemplo, se quiser construir um metrô que irá passar por diversas residências, estas só serão desapropriadas se tiverem prejuízos ao uso regular da residência, mas a escavação para os túneis que irão passar por debaixo dessas moradias.

\section{2. Órgãos que executam a desapropriação}

Além das entidades componentes da Federação que já conhecemos, que são a União, os Estados, os Municípios e o Distrito Federal, outros órgãos do governo poderão desapropriar.

Como nos ensina Kiyoshi Harada (2005, p. 69):

(...) Os concessionários de serviço público e os estabelecimentos de caráter público ou que exerçam funções delegadas de poder público, também podem expropriar, desde que autorizadas por lei ou contrato. Assim, Congás, Metrô, Sabesp, CDHU, Cesp etc., na esfera estadual, podem desapropriar. $\mathrm{Na}$ esfera municipal podem desapropriar a COHAB, a Emurb etc. Essas duas entidades já receberam a faculdade de promover a desapropriação nas próprias leis que autorizam sua criação. Na época de 70, a Emurb não só desapropriava para si, como também previa, por força contratual, desapropriações para Municipalidade 
de São Paulo, representando-a no pólo ativo, buscando, de um lado, as receitas que necessitava e, de outro lado, suprindo as deficiências do órgão municipal incumbido de oficiar nas expropriatórias. Hoje, a contratação da espécie não seria possível, pois a LOMSP (Lei Orgânica do Município de São Paulo) atribui de forma privativa a representação judicial do Município à Procuradoria-Geral do Município (art. 87)".

\section{Situações conflitantes}

a) Atos expropriatórios concorrentes

Quando duas entidades políticas, como Estado e Município, decretam a desapropriação de um mesmo estabelecimento, imagina-se que o Estado por sua posição superior ao Município possa usufruir de vantagem dessa disputa, porém, não ocorre desta maneira.

Ocorrendo essa circunstância, a soberania da União terá a faculdade de escolher um dos dois órgãos para desapropriar o lugar que está em conflito. Essa soberania decorre da aplicação da norma do \2o $^{\circ}$ do artigo $2^{\circ}$ do Decreto-lei 3.365/41, onde essa hipótese é conhecida como domínio eminente da União.

b) Desapropriação por autarquias e entidades paraestatais

$\mathrm{O} \S^{2} 2^{\circ}$ do artigo $2^{-}$do Decreto-lei, não se aplica a autarquias e entidades paraestatais. As autarquias não têm o poder de desapropriar. Por mais que se considere que as autarquias são pessoas jurídicas, elas só têm autonomia administrativa, com isso não poderão desapropriar qualquer território.

Diferentemente das autarquias, as entidades paraestatais podem livremente desapropriar, temos a exemplo a CDHU (representante do município de São Paulo), que se vale de um pressuposto falso de hierarquia, que data, muitas vezes práticas abusivas de desapropriação para a construção de casas populares.

\section{Da competência para legislar sobre desapropriação}

Quando analisamos a Constituição Federal de $1988 \mathrm{em}$ seu artigo 22, vemos que em regra, somente a União tem a competência para legislar sobre desapropriação. Porém, 
como exceção, vemos que um Estado poderá ter competência para tal ato, mediante Lei Complementar.

Como nos ensina Firmino Whitaker, que embora essa modalidade de intervenção do Estado estivesse prevista na Constituição Federal, o processo desta era regulado pela legislação estadual. A lei processual é, ainda, a de n.38, de i8.03.1836, que serve tanto para os casos de necessidade, como para os de utilidade, pois a competência do Estado, em matéria processual, é, hoje, ilimitada.

Também não podemos nos esquecer que legislar sobre desapropriação é diferente de declarar a expropriação (SALLES, p. 89), pois legislar sobre desapropriação significa fazer e decretar as leis sobre a desapropriação, e esta é feita pelo Poder Legislativo; enquanto que declarar a expropriação tem competência concorrente, dada pelos Entes Federativos (União, Estados, Distrito Federal e Municípios). Além desses, as pessoas indicadas em lei também podem declarar a expropriação, como é o caso da Agência Nacional de Energia - ANEEL, partindo do artigo io da Lei Federal n. 9.074/95, com a redação dada pela Lei Federal N. 9.648 em 1998 (GASPARINI, 2009, p. 891).

\section{Caducidade da declaração expropriatório}

Uma vez feita a declaração de utilidade pública, com todos os seus procedimentos, a administração tem em mãos o direito de desapropriar o imóvel do proprietário, mas tudo isso tem um prazo a ser seguido. Se passar muito tempo para a desapropriação o imóvel e a Administração Pública não o fizerem, o imóvel não poderá mais ser desapropriado. Isto ocorre pelo fenômeno da caducidade, ou seja, se houver descumprimento do prazo para a desapropriação, esta perde seu efeito e o bem permanecerá com o proprietário.

O prazo para caducar o direito de desapropriar o imóvel é de 5 anos, não podendo ser interrompida e nem suspenso por nenhum motivo, pois se trata de um prazo decadencial. O início da contagem do prazo para a caducidade da declaração expropriatória se dá pela data da publicação do decreto de utilidade pública.

Existem outros tipos de desapropriação, na qual veremos abaixo: 


\section{a) Desapropriação Amigável}

Existe uma outra modalidade de desapropriação, essa porém não causa conflitos entre as partes (expropriante e expropriado). Isso porque o expropriado autoriza amigavelmente a desapropriação. Esta é chamada de Desapropriação Amigável, devendo ocorrer por escritura pública, sempre que houver a concordância do expropriado (HARADA, 2005, p. 8I)

\section{b) Desapropriação Indireta}

A desapropriação indireta é a designação dada ao abuso e irregular apossamento do imóvel particular pela Administração Pública, com sua consequente integração no patrimônio público, sem obedecer às formalidades e cautelas do procedimento expropriatório.

Ocorrida esta, cabe ao lesado recurso às vias judiciais para ser plenamente indenizado, do mesmo modo que o seria caso o Estado houvesse procedido regularmente (MELLO, 2009, p. 882).

A desapropriação indireta é uma expropriação feita às avessas, pois não respeita o devido processo legal. Esta também pode ser chamada de desapossamento ou apossamento administrativo, pois o Poder Público se apossa do bem do particular, sem o consentimento do proprietário.

\section{Fases e etapas do procedimento de desapropriação}

Para que o processo integral desemboque-se na desapropriação de um bem é necessário a abrangência de procedimentos mistos que abarcam tanto a fase administrativa quanto a judicial, sendo ambas de vital importância para o regular andamento do feito.

Quando trata-se da função jurídico-operativa do instrumento expropriatório, cujo caráter trata-se do compulsório, faz-se necessário a incorporação do patrimônio ao acervo público, sendo que tal aquisição se dá em caráter originário. Mister salientar que a incorporação do bem objeto de desapropriação ao patrimônio público nem sempre é necessária e/ou obrigatória, ocorrerá, por exemplo, quando estivermos diante de casos cujo objetivo seja somente a extinção de direito, que precisa ser indenizado em virtude de sua 
proteção jurídica, sem necessidade de incorporá-lo ao patrimônio público. (ANDRADE, 2006.)

O instrumento jurídico da desapropriação foi delineado em função do alcance de finalidades específicas econômico-social e, em contrapartida, coberto pela compulsoriedade, objetivando alcançar com êxito ao efeito jurídico extintivo ainda que não seja essa a vontade do expropriado. Neste sentido a desapropriação sempre será uma forma compulsória de extinção da propriedade, uma vez que compele independentemente da vontade de seu titular, e, uma vez necessária a incorporação ao patrimônio público, é também uma forma originária de aquisição da propriedade, livre de ônus e vícios préadquidos.

\section{Fases do procedimento de desapropriação}

A fase administrativa do procedimento expropriatório é aquela que se processara exclusivamente no âmbito da Administração Pública, $\mathrm{O}$ ato de de maior valia na primeira fase é a declaração de utilidade pública ou interesse social, pois é em função deste ato, que permitisse-a iniciar a propositura da ação de desapropriação de fato e de direito, passando a estimar valores indenizatórios e de sua correspondente previsão orçamentária.

Superada a fase administrativa dá-se início a propositura da ação de desapropriação, fase judicial, indispensável para que o ato produza seus efeitos legais e próprios do instituto. Tanto a desapropriação por necessidade ou utilidade pública, quanto a por interesse social, seguem o rito ordinário previsto no DL 3.365/194I, aplicando-se no que precisar pela lacuna legislativa

o Código de Processo Civil, conforme dispõe os art. I9 do DL 3.365/41 e art. 5ํำ da Lei 4.132/1962. (ANDRADE, 2006.)

\section{Imissão provisória na posse}

A imissão provisória na posse é comumente usada quando presente os requisitos da necessidade publica, onde a atuação do poder público exige maior celeridade. Neste sentido, o juiz competente, após o ente expropriante comprovado a urgência e efetuado o 
devido depósito em juízo da quantia correspondente ao valor do imóvel, decretará a imissão provisória na posse.

São condições básicas para a imissão conforme dispõe o $\operatorname{art.} 15$, $\S^{{ }^{\circ}}$, do decreto lei $\mathrm{n}^{\circ} 3.365 / 4 \mathrm{I}$ as seguintes:

A) do preço oferecido, se este for superior a 20 (vinte) vezes o valor locativo, caso o imóvel esteja sujeito ao imposto predial; (Incluída pela Lei no 2.786, de 1956).

b) da quantia correspondente a 20 (vinte) vezes o valor locativo, estando o imóvel sujeito ao imposto predial e sendo menor o preço oferecido; (Incluída pela Lei no 2.786, de 1956).

c) do valor cadastral do imóvel, para fins de lançamento do imposto territorial, urbano ou rural, caso o referido valor tenha sido atualizado no ano fiscal imediatamente anterior; (Incluída pela Lei no 2.786, de 1956).

d) não tendo havido a atualização a que se refere o inciso c, o juiz fixará independente de avaliação, a importância do depósito, tendo em vista a época em que houver sido fixado originalmente o valor cadastral e a valorização ou desvalorização posterior do imóvel.

Importante destacar ainda que quando tratamos da imissão provisória, partimos do pressuposto que esta pode ser requerida em qualquer modalidade expropriatória, isto é, nas desapropriações fundadas na necessidade pública, utilidade pública e interesse social. (Mazza, 2013, P. 638),

\section{CONCLUSÃO}

Em suma, fica claro que a desapropriação é a maneira mais influente de intervenção do Estado, pois constitui-se como instrumento legal para que ocorra a retirada do proprietário de seu imóvel, e desta forma opõem-se à garantia constitucional da propriedade.

Aqui são demonstradas várias formas e motivos, nos quais o proprietário perde o direito sobre seu bem.

Quando uma propriedade não cumpre sua função social, esta poderá ser desapropriada.

Poderíamos, aqui, citar como exemplo uma área com vocação agrícola e que não é utilizada com a intenção clara e insofismável de espera de valorização. Permitir a 
manutenção da propriedade nestas condições seria beneficiar alguém que, impatrioticamente, procura obter vantagens indevidas.

Esta situação requer uma desapropriação urgente, visando o bem comum, que neste caso se sobrepõe sobre o bem individual.

Concluímos que o instituto da desapropriação é uma ferramenta importantíssima para que o Poder Público possa traçar novos rumos de desenvolvimento, defender a coletividade e ampliar o progresso de um Município, de um Estado e de uma Nação.

Nos procedimentos da desapropriação, a respeitosa obediência aos ditames legais é fundamental para que as leis, os códigos, os estatutos cumpram suas funções reguladoras e encontrem respaldo nos ordenamentos da nossa Constituição.

O todo aqui exposto é de suma importância para que as políticas sociais sejam efetivamente exercidas, vez que, na desapropriação sobressaem os interesse público em detrimento dos privados. Estando o direito coletivo avultado sobre o interesse individual, cada modalidade de desapropriação ( Necessidade Pública, Utilidade Pública, e Interesse Social) traz consigo objetivos burilados o bastante para que atinjam o progresso social, aprovisionando certas necessidades pensando, em contrapartida, no menor dano possível ao patrimônio individual.

Faz-se de vital importância a observância de regulamentos e a judicialização dos procedimentos que entornam a desapropriação, garantindo o princípio da isonomia, (tratar igualmente os iguais e desigualmente os desiguais nas medidas de suas desigualdades) e a devida compensação do título em troca da lesão advinda pela expropriação do bem, assim logra-se um equilíbrio remido.

\section{REFERÊNCIAS BIBLIOGRÁFICAS}

ANDRADE, Letícia Queiroz de. Desapropriação de bens públicos à luz do princípio federativo. São Paulo: Malheiros Editores, 2006.

BASTOS, Celso Ribeiro. Curso de Direito Administrativo - $\mathrm{I}^{\underline{a}}$ edição. Celso Bastos Editora, São Paulo, 2002. 
GASPARINI, Diógenes. Direito Administrativo - I4 $4^{\underline{a}}$ edição: Editora Saraiva. São Paulo, 2009 .

HARADA, Kiyoshi. Desapropriação - $5^{\text {a }}$ edição. Editora Atlas. São Paulo, 2005.

MAZZA, Alexandre. Manual de Direito Administrativo. $3^{\underline{a}}$ ed. São Paulo: Saraiva 2013.

MELlO, Celso Antônio Bandeira de. Curso de Direito Administrativo - $26^{\underline{a}}$ edição: Malheiros Editores. São Paulo, 2009.

MEIRELLES, Hely Lopes. Direito Municipal brasileiro. Hely Lopes Meirelles. Malheiros, São Paulo, 1994.

MIRANDA, Pontes de. Comentários à Constituição de 1967. Revista dos Tribunais. t5. São Paulo, 1968.

SALLES, José Carlos de Moraes. A Desapropriação à luz da doutrina e da jurisprudência 6 ${ }^{\mathrm{a}}$ edição, Editora Revista dos Tribunais. São Paulo, 2009.

SODRÉ, Eurico. A desapropriação - 3a edição. Saraiva. São Paulo, 1955. 